\title{
ANALISIS EFEKTIFITAS HORMON TIROKSIN TERHADAP PERTUMBUHAN BENIH IKAN NILA SALIN (Oreochromis niloticus)
}

\author{
Analysis of The Effectiveness of Thyroxin Hormone on The Growth of Salina Tilapia (Oreochromis Niloticus) \\ Matius Petrus Sroyer ${ }^{1}$, Hadijah $^{2}$, Sri Mulyani $^{2}$ \\ ${ }^{1}$ Balai Benih Ikan Pantai Kabupaten Biak \\ ${ }^{2}$ Program Studi Budidaya Perairan Program Pascasarjana Universitas Bosowa \\ Email: petrusunb@gmail.com \\ Diterima: 30 April 2020 \\ Dipublikasikan: 05 Juni 2020
}

\begin{abstract}
ABSTRAK
Tujuan dari penelitian ini untuk mengetahui pengaruh hormon tiroksin terhadap pertumbuhan ikan nila salin dengan beberapa konsentrasi yang berbeda dan secara oral. Penelitian ini dilakukan secara eksperimental dengan 4 perlakuan yaitu penambahan hormone Tiroksin pada pakan 10 $\mathrm{g} / \mathrm{kg}$ pakan pada P1, 15g/kg pada P2, $25 \mathrm{~g} / \mathrm{kg}$ pada P3 dan tanpa pemberian hormone pada pakan untuk control ada P4. Data dianalisis dengan menggunakan analysis of variance (ANOVA). Parameter uji dalam penelitian ini meliputi Laju Pertumbuhan Spesifik dan Pertumbuhan Mutlak. Hasil penelitian menunjukkan laju pertumbuhan 3,01-4,73\%/hari, pertumbuhan mutlak 103,78 - 159,04 gram, sehingga penggunaan hormone Tiroksin terbaik 25 gram $/ \mathrm{kg}$ pakan.
\end{abstract}

Kata Kunci: Nila Salin, Tiroksin, Pertumbuhan

\section{ABSTRACT}

The purpose of this study was to determine the effect of the thyroxine hormone on the growth of salted tilapia with several different concentrations and it's done orally. This study was carried out experimentally with 4 treatments, namely the addition of the hormone thyroxine $10 \mathrm{~g} / \mathrm{kg}$ feed at P1, $15 \mathrm{~g} / \mathrm{kg}$ feed at P2, $25 \mathrm{~g} / \mathrm{kg}$ feed at P3 and without addition of hormones to feed for control at P4. The data were analyzed using analysis of variance (ANOVA). Test parameters in this study include the Specific Growth Rate and Absolute Growth. The results showed a growth rate of 3.01-4.73\%/day and absolute growth of 103.78-159.04 grams, so that the best use of thyroxine hormone was $25 \mathrm{~g} / \mathrm{kg}$ feed.

Keywords: Tilapia, Thyroxine, Growth

\section{PENDAHULUAN}

Ikan Nila Salin (Oreochromis niloticus) adalah ikan Nila yang sudah dilakukan inovasi bioteknologi dan rekayasa rekayasa sehingga memiliki keunggulan dibandingkan dengan beberapa komoditas ikan Nila air tawar pada umumnya, seperti pertumbuhannya yang cepat, mudah untuk dikembangbiakkan, mudah dalam pemeliharaan dan adaptasi yang tinggi terhadap perubahan lingkungan. Karena beberapa keunggulan tersebut maka ikan nila Salin menjadi incaran pembudidaya baik air payau maupun pembudidaya ikan laut, dan permintaan pasarnyapun mengikuti semakin dikenalnya ikan tersebut.

Salah satu upaya untuk memenuhi pasar yang tinggi mulai dilakukan pendekatan molekuler dengan melakukan aplikasi hormone pertumbuhan sehingga masa pemeliharaan bisa dipercepat, waktu panen juga dipersingkat dan efisiensi biaya produksi dapat lebih dilakukan.

Mekanisme langsung adalah hormone pertumbuhan akan berikatan dengan reseptornya dan mempengaruhi pertumbuhan di organ target, sedangkan mekanisme tidak langsung adalah mekanisme aksi hormon yang dimediasi oleh insulin-like growth factor-I (IGF-I) di dalam hati. Beberapa tahun terakhir hormone Tiroksin menjadai salah satu hormone pertumbuhan yang sering digunakan di dalam budidaya ikan apalagi sejak Turner dan Bagnara 1976 menemukan bahwa hormone
Tiroksin ini berperan penting dalam proses perkembangan dan pertumbuhan jaringan serta proses metabolism pada saluran pencernaan pada ikan.

Hormon Tiroksin juga dapat memicu produksi GH, pigmentasi dan meningkatkan aktivitas spesifik enzim oksidatif dan efisiensi fosforilasi Matty (1985). Selanjutnya oleh GH juga bertanggung jawab dalam pembentukan sistem Imun dan mengatur tekanan osmosis pada ikan Telostei, mengatur aktivitas lipotik dan anabolisme protein pada vertebrata, pemberian rGH ikan mas mampu meningkatkan bobot ikan mas sebesar $53,1 \%$. peningkatan bobot $20,94 \%$ pada kerapu Kertang (Alimuddin et al 2010 dan peningkatan bobot $75 \%$ pada ikan Gurame.

\section{METODE PENELITIAN}

\section{Waktu dan tempat}

Penelitian ini dilaksanakan di Balai Perikanan Budidaya benih Ikan Pantai (BPIP) Biak-Papua dan untuk analisa laboratorium menggunakan fasilitas Laboratorium Dinas Perikanan Kabupaten Biak dan Stasiun LAPAN Biak. Penelitian ini dilakukan pada bulan Agustus hingga Desember 2019. 


\section{Metode penelitian}

Penelitian ini merupakan jenis penelitian kuantitatif. Ikan yang di digunakan uji yang digunakan pada penelitian adalah benih ikan nila Salin (Oreochromis niloticus) ukuran $3-5 \mathrm{~cm}$. Pakan uji yang digunakan yaitu pakan komersial dengan komposisi kandungan Protein Min $30 \%$ Lemak Min $5 \%$ Serat Maks $8 \%$, Abu Maks $13 \%$, Air Maks $12 \%$, yang telah diberi perlakuan penambahan hormone Tiroksin sesuai perlakuan pada penelitian. Pemberian pakan dilakukan sebanyak 4 kali sehari dengan dosis sebanyak $5 \%$ dari bobot tubuh setiap hari. Penelitian ini bersifat Eksperimental dengan metode Rancangan Acak Lengkap dengan 3 perlakuan dan 4 ulangan, yaitu:

- Perlakuan P1 = penambahan hormone Tiroksin 10 $\mathrm{g} / \mathrm{kg}$ pakan Perlakuan P2 = Penambahan HT $15 \%$

- $\quad$ Perlakuan P3 = Penambahan HT 25\%

- $\quad$ Perlakuan P4 = Tanpa pemberian hormone Tiroksin

\section{Parameter uji}

\section{Laju Pertumbuhan Spesifik}

Laju pertumbuhan spesifik merupakan parameter untuk mengamati tingkat pertumbuhan dan presentase pemambahan bobot harian (Effendie, 1997).

$$
\mathrm{SGR}=\frac{\ln W t-\ln W o}{t} \times 100 \%
$$

SGR= Laju pertumbuhan spesifik (g/hari)

$\mathrm{Wt}=$ Bobot rata-rata ikan pada hari ke-t $(\mathrm{g})$

Wo $=$ Bobot rata-rata ikan di awal penelitian $(\mathrm{g})$

$\mathrm{t} \quad=$ Waktu penelitian (hari)

\section{Pertumbuhan mutlak}

Pertumbuhan mutlak merupakan parameter untuk mengukur laju pertumbuhan total ikan selama masa pemeliharaan (Effendie, 1997).

$\mathrm{W}_{\mathrm{m}}=\mathrm{W}_{\mathrm{t}}-\mathrm{W}_{0}$

$\mathrm{W}_{m}=$ Pertumbuhan berat mutlak (Gram)

$\mathrm{W}_{t}=$ Berat biomassa pada akhir penelitian (Gram)

$\mathrm{W} o=$ Berat biomassa pada awal penelitian (Gram).

\section{HASIL DAN PEMBAHASAN}

\section{Laju Pertumbuhan Spesifik}

Berdasarkan pengamatan laju pertumbuhan spesifik, menunjukkan bahwa rata-rata pertumbuhan spesifik ikan nila berada pada kisaran 3,01-4,73\%/hari.

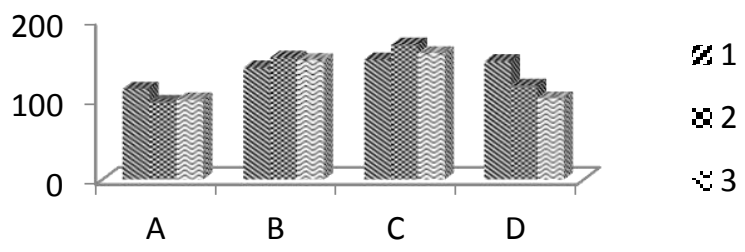

Gambar 1. Diagram Laju Pertumbuhan Spesifik
Perlakuan yang menghasilkan rata-rata pertumbuhan harian tertinggi adalah perlakuan C. sebesar $4,73 \%$ /hari yang tidak berbeda jauh dengan perlakuan B sebesar 4,70\%/hari, disusul perlakuan D sebesar 3,32\%/hari, sedangkan perlakuan yang menghasilkan pertumbuhan harian terendah adalah perlakuan A (sebesar 3,01\%/hari.)

Hasil analisis menunjukkan bahwa terdapat perbedaan signifikan keempat perlakuan terhadap SGR, dimana nilai $\mathrm{F}$ sebesar 9,512dengan tingkat signifikansi 0,005 ( $\operatorname{sig}<0,05)$. Hasil uji lanjut dengan uji Tukey menunjukkan bahwa tidak terdapat perbedaan signifikansi antara perlakuan A dengan perlakuan $\mathrm{D}$, tidak terdapat perbedaan signifikan $\mathrm{D}$ dan $\mathrm{B}$, dan tidak terdapat perbedaan signifikan perlakuan B dan C. Sedangkan perlakuan A dan $\mathrm{D}$ berbeda signifikan dengan perlakuan B dan C. Sedangkan perlakuan D \& B berbeda nyata dengan Perlakuan C dan A.

Pertumbuhan adalah penambahan ukuran, baik berat maupun panjang. Salah satu yang mempengaruhi pertumbuhan adalah pakan (fujaya, 2004). Hubungan panjang dan berat hampir mengikuti hukum kubik yaitu berat ikan sebagai pangkat tiga dari panjangnya. Tetapi hubungan yang terdapat pada ikan sebenarnya tidak demikian karena bentuk dan panjang ikan berbeda-beda. (Effendi. 2002). Perbedaan nilai berat pada ikan tidak saja antara populasi yang berbeda dari spesies yang sama, tetapi juga antara populasi yang sama pada tahun yang berbeda yang barangkali dapat diasosiasikan dengan kondisi nutrisi mereka, hal ini bisa terjadi karena pengaruh faktor ekologis dan biologis (Ricker, 1975).

Menurut Effendie (2002), pertumbuhan dipengaruhi oleh faktor internal dan eksternal. Faktor internal sebagian besar tergantung pada tubuh ikan tersebut, misalnya kemampuan ikan untuk memanfaatkan sisa energi dan protein setelah metabolisme untuk pertumbuhannya, sedangkan faktor eksternal seperti faktor lingkungan dan pakan sangat berpengaruh pada pertumbuhan ikan. Kedua faktor tersebut akan menyeimbangkan keadaan tubuh ikan selama dalam media pemeliharaan dapat menunjang pertumbuhan tubuh ikan. Pertumbuhan dipengaruhi oleh keseimbangan nutrien yang ada didalam pakan. Nutrien seimbang akan menghasilkan partumbuhan yang baik. Pertumbuhan terjadi apabila ada kelebihan energi bebas setelah energi yang tersedia digunakan untuk pemeliharaan tubuh. Pertumbuhan ikan dapat terjadi jika jumlah nutrisi pakan yang dicerna dan diserap oleh ikan lebih besar dari jumlah yang diperlukan untuk pemeliharaan tubuhnya. Pertumbuhan terjadi apabila terdapat kelebihan input energi dan asam amino (protein) yang berasal dari pakan. Energi tersebut akan digunakan untuk metabolisme, gerak, reproduksi dan menggantikan sel-sel yang rusak (Effendie, 2002)

Kecepatan laju pertumbuhan ikan sangat dipengaruhi oleh jenis dan kualitas pakan yang diberikan serta kondisi lingkungan hidupnya. Apabila pakan yang diberikan berkualitas baik, jumlahnya mencukupi dan kondisi lingkungan mendukung maka dapat dipastikan laju pertumbuhan ikan menjadi cepat sesuai yang diharapkan. Sebaliknya, apabila pakan yang diberikan berkualitas jelek, jumlahnya tidak mencukupi dan kondisi lingkungannya tidak mendukung dapat dipastikan pertumbuhan ikan akan terhambat (Amri dan Khairuman 2002). 


\section{Pertumbuhan Mutlak}

Berdasarkan pengamatan pertumbuhan mutlak, seperti terlihat pada gambar tabel dibawah sebagi berikut :

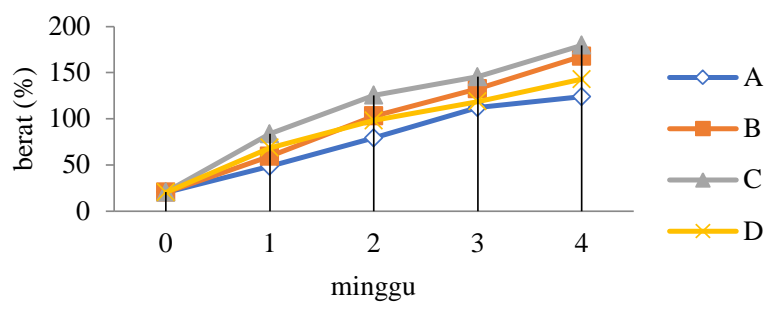

Gambar 2. Perubahan Berat Rata-Rata Ikan Nila

Berat rata-rata ikan nila setiap perlakuan meningkat seiring dengan lamanya pemeliharaan. Dengan demikian dapat dinyatakan bahwa pada setiap pakan dengan penambahan hormon atau tidak masih memberikan kondisi lingkungan budidaya yang baik bagi ikan nila karena masih menunjukkan peningkatan berat setiap minggu. Penambahan hormon Tiroksin pada ikan nila secara biologis di dalam wadah terbatas memiliki sifat-sifat yang dapat bersinergi sehingga pada sistem ini, ikan nila tetap tumbuh meskipun padat penebarannya meningkat. Hal ini diduga disebabkan oleh kondisi kualitas air yang dikelola selama penelitian, baik pada perlakuan penggunaan hormone maupun tanpa pemberian hormone pertumbuhan relatif baik yang berada pada kisaran yang dapat ditolerir oleh ikan nila.

Pertumbuhan mutlak ikan nila yang dipelihara secara terkontrol pada setiap perlakuan menunjukkan pola yang sama pada pertumbuhan harian sebagaimana ditunjukkan pada Gambar 3. Rata-rata pertumbuhan mutlak ikan nila yang dipelihara selama kurang lebih 4 minggu 133,18 atau berada pada kisaran 103,78 - 159,04 gram. Perlakuan yang menghasilkan pertumbuhan mutlak tertinggi adalah perlakuan $\mathrm{C}$ sebesar 159.04 gr disusul perlakuan B sebesar 147,44 gr dan perlakuan D sebesar 122,46 gr, sedangkan perlakuan yang menghasilkan pertumbuhan mutlak terendah adalah perlakuan A sebesar 103,78 gr.

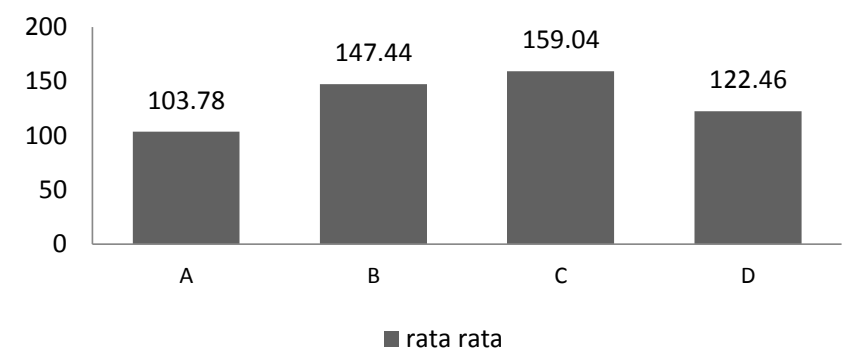

Gambar 3. Pertumbuhan Mutlak Ikan Nila
Hasil analisis menunjukkan bahwa terdapat perbedaan signifikan keempat perlakuan terhadap pertumbuhan mutlak, dimana nilai $\mathrm{F}$ sebesar 9,591 dengan tingkat signifikansi 0,005 (sig< 0,05). Hasil uji lanjut dengan uji Tukey diatas menunjukkan bahwa tidak terdapat perbedaan signifikansi antara perlakuan A dengan perlakuan $\mathrm{D}$, tidak terdapat perbedaan signifikan $\mathrm{D}$ dan $\mathrm{B}$, dan tidak terdapat perbedaan signifikan perlakuan B dan C. Sedangkan perlakuan A berbeda signifikan dengan perlakuan B dan C. Sedangkan perlakuan D berbeda nyata dengan Perlakuan C dan A. Fujaya (2004) mengatakan cepat tidaknya pertumbuhan ikan ditentukan oleh banyaknya protein yang dapat diserap dan dimafaatkan oleh tubuh sebagai zat pembangun

\section{KESIMPULAN}

Berdasarkan hasil penelitian, dapat disimpulkan Hormone pertumbuhan Tiroksin berpengaruh nyata terhadap partumbuhan harian 3,01-4,73\%/hari, pertumbuhan mutlak 103,78 159,04 gram dan memperoleh kelangsungan hidup. 43,33 96,67 \%. Dosis terbaik pemberian 37ormone pertumbuhan untuk ikan nila adalah $25 \mathrm{mg} / \mathrm{kg}$ pakan. Peneliti merekomendasikan perlu dilakukan penelitian lanjutan mengenai pengaruh padat tebar terhadap pertumbuhan dan sintasan ikan nila (Oreochromis niloticus sp) serta biomassa pada skala yang lebih besar di tambak.

\section{DAFTAR PUSTAKA}

Amri, K dan Khairuman 2003. Budidaya Ikan Nila Salin Secara Intensif. Jakarta: PT. Agro Media

Effendi, I. 1997. Biologi Perikanan. Yayasan Pustaka Nusantara. Yogyakarta.

Effendie, M .I. (2002). Biologi perikanan. Yayasan Pustaka Nusantara. Yogyakarta

Fujaya, Y. (2004). Fisiologi Ikan. Dasar Pengembangan Teknik Perikanan. PT. Rineka Cipta, Jakarta.

Handoyo B. 2013. Respons Benih Ikan Nila Salin Ter-Hadap Hormon Pertumbuhan Rekombinan Ikan Kerapu Kertang Melalui Perendaman Dan Oral. Tesis. Institut Pertanian Bogor. 53 hlm.

Hardiantho D, Alimuddin, Prasetiyo AE, Yanti DH, Sumantadinata K. 2012. Performa Benih Ikan Nila Salin Diberi Pakan Mengandung Hormon Pertumbuhan Rekombinan Ikan Mas Dengan Dosis Berbeda. Jurnal Akuakultur Indonesia, 11(1):17-22.

Leedom TA, Uchida K, Yada T, Richman NH, Byatt JC, Collier RJ, Hirano T, Grau EG. 2002. Recombinant Bovine Growth Hormone Treatment of Tilapia: Growth Response, Meta-Bolic Clearance, Receptor Binding And Immunoglobulin Production. Aquaculture, 207(34):359-380.

Matty, A.J. 1985. Fish Endocrinology. Croom Helm London and Sydney Timber Press Portland, Oregon

Santiesteban D, Martín L, Arenal A, Franco R, Sotolongo J. 2010. Tilapia Growth Hormone Binds to a Receptor In Brush Border Membrane Vesicles From The 
Hepatopancreas Of Shrimp (Litopenaeus vannamei). Aquaculture, 306(1-4):338-342.

Turner, C. D., and J. T. Bagnara, 1976. General

Endocrinology. 6 thEd. W. B. Sauders Company.

Philadelphia. 